\title{
OCCURRENCE OF Ancylostoma IN DOGS, CATS AND PUBLIC PLACES FROM ANDRADINA CITY, SÃO PAULO STATE, BRAZIL
}

Willian Marinho Dourado COELHO(1), Alessandro Francisco Talamini do AMARANTE(2), Juliana de Carvalho APOLINÁRIO(3), Natalia Marinho Dourado COELHO(4) \& Katia Denise Saraiva BRESCIANI(4)

\begin{abstract}
SUMMARY
The aim of this study was to determine the frequency and intensity of Ancylostoma spp. in 33 dogs and 52 cats by means of coproparasitological examinations and parasitological necropsy, and assess the presence of contaminated feces with eggs of that parasite in public places of Andradina Municipality, São Paulo State, Brazil. Willis-Mollay and Sedimentation methods indicated Ancylostoma spp. eggs in $87.8 \%$ (29/33) dogs and 94.2\% (49/52) cats. The species A. caninum and A. braziliense were found in $63.6 \%$ $(21 / 33)$ and $30.3 \%$ (10/33) of dogs, respectively. Considering cats, $67.3 \%$ (35/52) were parasitized by A. braziliense, 21.1\% (11/52) by A. caninum, and $9.6 \%(5 / 52)$ by A. tubaeforme. Forty-two canine fecal samples were collected from public environments, including 23 squares/gardens and 19 streets/sidewalks. Positive samples for Ancylostoma spp. accounted for 64.3\% (27/42); squares/gardens had $60.9 \%(14 / 23)$ positive samples, and streets and sidewalks, 68.4\% (13/19). No association was observed between the number of Ancylostoma spp parasites and age, sex and breed of the animals and also the ratio of EPG counts and the parasitic intensity observed at necropsy $(p>0.05)$. Based on the high occurrence of hookworm in dogs and cats in this study, the treatment with anti helminthics are needed even in those animals with negative stool tests, besides adopting control of the number of animals in public places, in order to decrease the likelihood of environmental contamination, since this parasite represents a potential hazard to human and animal health.
\end{abstract}

KEYWORDS: Ancylostomiasis; Cutaneous larva migrans; Helminths; Small animals; Zoonosis.

\section{INTRODUCTION}

The urban development and environmental changes caused by humans have increased the occurrence of parasitic zoonoses emerging and re-emerging ${ }^{4}$. Dogs $\mathrm{s}^{5,22,24}$ and cats ${ }^{1,6,18}$ can act as reservoirs of evolutive parasitic forms that contaminate the environment with their feces, mainly with infective larvae of hookworms, representing a serious public health problem ${ }^{14}$. This fact is confirmed by the work of SANTARÉM et al. (2004), which detected the occurrence of Cutaneous Larva Migrans (CLM) in children from Taciba Municipality, São Paulo State, Brazil, due to their contact with sand in public parks where Ancylostoma spp. larvae were found.

Some species of Ancylostoma present zoonotic potential ${ }^{8}$, as Ancylostoma braziliense and Ancylostoma caninum, who are the etiologic agents of the diseases known as cutaneous larva migrans ${ }^{9}$ and eosinophilic enteritis ${ }^{16}$.

The aim of this study was to determine the occurrence of Ancylostoma sp. in domestic dogs and cats by means of coproparasitological examinations and parasitological necropsy, and evaluate the occurrence of this parasite in public places of Andradina Municipality, São Paulo, Brazil.

\section{MATERIAL AND METHODS}

In this study 33 dogs and 52 cats were included. The animals were captured or delivered by their owners to the Center for Zoonosis Control (CZC) of Andradina Municipality, (20.8961 ${ }^{\circ}$ South, 51.37944 West and at $405 \mathrm{~m}$ altitude) for euthanasia. Of the dogs analyzed, 19 were females and 14 males being, 24 without defined breed (WDB) and nine with defined breed (DB). The group of cats consisted of 30 males and 22 females, with 47 WDB and five with DB.

The age of the animals was estimated according to the analysis of the dental arcade, being classified as young (until one year), adult (between one and seven years) and elderly (over seven years of age). Among the dogs, seven were young, 21 adults and five elderly. Of the cats, 18 were young, 30 adults and four elderly.

This procedure was previously approved by the Animal Experimentation Ethics Committee of the São Paulo State University

Financial support: The São Paulo State Research Foundation - FAPESP

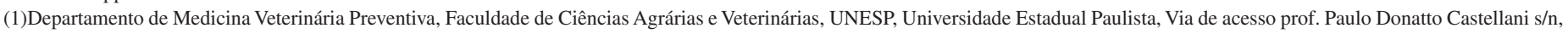
14884-900 Jaboticabal, São Paulo, Brasil. 
COELHO, W.M.D.; AMARANTE, A.F.T.; APOLINÁRIO, J.C.; COELHO, N.M.D. \& BRESCIANI, K.D.S. - Occurrence of Ancylostoma in dogs, cats and public places from Andradina city, São Paulo State, Brazil. Rev. Inst. Med. Trop. Sao Paulo, 53(4): 181-4, 2011.

(FOA-UNESP), Araçatuba, protocol number 2007-003276.

Feces were collected directly from the rectum of each animal and later processed by flotation techniques in sodium chloride saturated solution with 1.182 density (Willis-Mollay Technique) and spontaneous sedimentation in water ${ }^{12}$. The fecal egg counts (EPG), according to GORDON \& WHITLOCK (1939), was performed to associate the excretion of eggs and the intensity of Ancylostoma detected in necropsied animals.

To recover adult helminths, each animal was necropsied and the contents from their stomach, and small and large intestines were washed in tap water, sieved and stored in properly identified containers with formaldehyde $10 \%$ buffered solution. The contents were then placed onto Petri plates and observed under a stereomicroscope; helminths were collected with entomological stylets and later transferred to test tubes containing alcohol $70 \%$.

Statistical analysis was performed using the Fisher Exact Test, considering the occurrence of Ancylostoma spp. The Chi-square test $\left(\chi^{2}\right)$ was used to associate sex, age, breed, level of EPG with the parasitic intensity observed in the necropsy, and the occurrence of single or mixed infections, considering as significant $p<0.05$.

\section{RESULTS}

Ancylostoma species were identified based on the morphology of their buccal capsule and teeth under a phase contrast microscope (Olympus ${ }^{\circledR}$, USA) at 400x magnification, after clarification with acetic acid $80 \%{ }^{29}$.

Forty-two fecal samples were also collected from public environments, including 23 squares/gardens and 19 streets/sidewalks. The samples were collected using disposable procedure gloves, and stored in polystyrene box with ice during the transportation to the laboratory.

The occurrence of Ancylostoma in dogs and cats are shown in Table 1. In the dogs and cats, respectively there was NO association between sex $\left(\chi^{2} 1.9775 ; p=0.2882\right)$ and $\left(\chi^{2} 0.7739 ; p=0.5670\right)$, age $\left(\chi^{2} 0.8128 ; p=1.0000\right)$ and $\left(\chi^{2} 10.6122 ; p=0.0232\right)$, and breed $\left(\chi^{2} 1.1853 ; p=0.2952\right)$ and $\left(\chi^{2} 11.9233 ; p=0.0217\right)$ with the presence of Ancylostoma, as well as the occurrence of single infections and co-

Table 1

Occurrence of different species of Ancylostoma species in dogs and cats from Andradina Municipality, São Paulo State, Brazil

\begin{tabular}{lcccc}
\hline Ancylostoma specie & \multicolumn{2}{c}{ Dogs $(\mathrm{n}=33)$} & \multicolumn{2}{c}{ Cats $(\mathrm{n}=52)$} \\
\cline { 2 - 5 } & Positive & $\%$ & Positive & $\%$ \\
\hline A. caninum & 21 & 63.6 & 35 & 67.3 \\
A. braziliense & 10 & 30.3 & 11 & 21.1 \\
A. tubaeforme & 0 & 0 & 5 & 9.6 \\
${\text { A.caninum }+ \text { A. } \text { braziliense }^{*}}^{\text {Total }}$ & 7 & 21.2 & 9 & 17.3 \\
\hline
\end{tabular}

$\mathrm{n}=$ number of animals examined; ${ }^{*}$ parasites observed simultaneously, included on lines of A. caninum and A. braziliense infections by different species of Ancylostoma $\left(\chi^{2} 4.5455 ; p=0.033\right)$ and $\left(\chi^{2} 1.1429 ; p=0.2850\right)$. Likewise, the ratio of EPG counts and the parasitic intensity observed at necropsy in $\operatorname{dogs}\left(\chi^{2} 2.0000 ; p=0.1573\right)$ and cats $\left(\chi^{2} 2.4545 ; p=0.1172\right)$, did not differ statistically.

\section{DISCUSSION}

Eggs of Ancylostoma spp. were detected in 64.2\% (27/42) samples collected from the environment, and positivity percentages were similar $\left(\chi^{2} 0.5807 ; p=0.7480\right)$ between feces from squares/gardens, $60.8 \%$ (14/23), and those from streets/sidewalks, 68.4\% (13/19). Compared to our results, lower percentages of the genus Ancylostoma in dogs have been reported in Poland ${ }^{3}$, Venezuela ${ }^{23}$, United States ${ }^{7}$ and other regions of Brazil ${ }^{30}$.

Using parasitological necropsy, YACOB et al. (2007), in Ethiopia, and KLIMPEL et al. (2010), in Brazil, reported the occurrence of A. caninum in $70 \%(14 / 20)$ and $95.6 \%$ (44/46) respectively, in the examined dogs. These values are lower and higher, respectively, when compared with those observed in the present study for Ancylostoma species. In cats, also using the parasitological necropsy, ISHIZAKI et al. (2006) found $66.6 \%$ (40/60) of A. braziliense and 18.3\% (11/60) of A. tubaeforme, corroborating with the findings of our study and those of OGASSAWARA et al. (1986) who found 37\% (20/54) of A. braziliense and 25.9\% (14/54) of A.caninum/tubaeforme. Similarly, the predominance of A. braziliense (70.9\%) relative to A. caninum $(36.7 \%$ ) was observed in 196 cats from Ribeirão Preto Municipality, São Paulo State, Brazil, by ZAGO-FILHO et al. (1957). Unlike our study, MILLÁN \& CASANOVA (2009), in Spain, observed that $A$. tubaeforme was the specie with the highest prevalence in cats. These differences are mostly due to the fact that $A$. tubaeforme is the dominant cat species in Europe (DUARTE et al., 2010).

Although A. caninum is not considered as a common species in cats, similarly to our work, OGASSAWARA et al. (1986) showed a high occurrence of A. caninum in cats from São Paulo, Brazil, and BAKER et al. (1989) found $5.2 \%(78 / 1502)$ of occurrence of this specimen in young cats in Africa. These observations elucidate that, eventually, the cat can be considered as a host of A. caninum, as previously demonstrated by SCOTT (1928) and FOSTER \& CORT (1937).

As for the agreement between the coproparasitological values and necropsy, our results differ from those obtained by SOUZA-DANTAS et al. (2007), who found a positive association between the numbers of eggs shedding and intensity of adult forms recovered at necropsy.

Animal feces contaminating the soil have been reported in several studies. Higher ${ }^{25}$ and lower ${ }^{21}$ percentages than those detected in the present study have been presented. Using Willis technique, SILVA FRANCISCO et al. (2008) evaluated 66 fecal samples of dogs and cats from public squares of Anápolis Municipality, Goiás State, Brazil, and observed Ancylostoma eggs and larvae in 46.9\% (31/66) and 15.1\% $(10 / 66)$ samples, respectively.

Public squares particularly present a high level of contamination by enteroparasites, mainly Ancylostoma ${ }^{19}$. The occurrence of CLM in children from Taciba Municipality, São Paulo State, Brazil, was observed, due to their contact with sand in public parks where Ancylostoma spp. larvae were detected ${ }^{27}$. 
COELHO, W.M.D.; AMARANTE, A.F.T.; APOLINÁRIO, J.C.; COELHO, N.M.D. \& BRESCIANI, K.D.S. - Occurrence of Ancylostoma in dogs, cats and public places from Andradina city, São Paulo State, Brazil. Rev. Inst. Med. Trop. Sao Paulo, 53(4): 181-4, 2011.

\section{CONCLUSION}

Based on the high occurrence of hookworm in dogs and cats in Andradina, the treatment with anti helminthics are needed even in those animals with negative stool tests, besides adopting control of the number of animals in public places, in order to decrease the likelihood of environmental contamination, since this parasite represents a potential hazard to human and animal health.

\section{RESUMO}

\section{Ocorrência de Ancylostoma em cães, gatos e locais públicos da cidade de Andradina, São Paulo, Brasil}

O objetivo deste estudo foi determinar a freqüência e intensidade parasitária de Ancylostoma spp. em 33 cães e 52 gatos por meio de exames coproparasitológicos e pela necropsia parasitológica, bem como avaliar a presença de fezes contaminadas com ovos deste parasito em locais públicos do município de Andradina/SP. Por meio das técnicas de WillisMollay e Sedimentação, ovos de Ancylostoma spp. foram observados em $87,9 \%$ (29/33) e $94,2 \%$ (49/52) dos cães e gatos, respectivamente. As espécies constatadas nos cães foram A. caninum em 63,6\% (21/33) e A. braziliense em 30,3\% (10/33). Dos gatos, 67,3\% (35/52) estavam parasitados por A. braziliense, 21,1\% (11/52) por A. caninum e $9,6 \%$ (5/52) por A. tubaeforme. Foram coletadas 42 amostras fecais caninas do ambiente público sendo, 23 de praças/jardins e 19 de ruas/calçadas. Positividade para Ancylostoma spp. foi observada em 64,3\% (27/42) destas fezes sendo 60,9\% (14/23) provenientes de praças/jardins e 68,4\% (13/19) de ruas e calçadas. Não foi observada associação entre a presença do parasito e a idade, sexo e raça dos animais, bem como entre o número de parasitos observado na necropsia e o OPG $(p>0.05)$. Baseado na alta ocorrência de ancilostomídeos em cães e gatos neste estudo, o tratamento com anti-helmínticos faz-se necessário, mesmo nos animais com exames de fezes negativos, além da necessidade de adoção de controle do número de animais em locais públicos, a fim de diminuir a probabilidade de contaminação do meio ambiente, uma vez que este parasito representa um perigo potencial à saúde humana e animal.

\section{REFERENCES}

1. Abu-Madi MA, Behnke JM, Prabhaker KS, Al-Ibrahim R, Lewis JW. Intestinal helminths of feral cat populations from urban and suburban districts of Qatar. Vet Parasitol. 2010;168:284-92.

2. Baker MK, Lange L, Verster A, van der Plaat S. A survey of helminths in domestic cats in the Pretoria area of Transvaal, Republic of South Africa. Part 1: the prevalence and comparison of burdens of helminths in adult and juvenile cats. J S Afr Vet Assoc. 1989;60:139-42.

3. Borecka A. Prevalence of intestinal nematodes of dogs in Warsaw area, Poland Helminthologia. 2005;42:35-9.

4. Bradley CA, Altizer S. Urbanization and the ecology of wildlife diseases. Trends Ecol Evol. 2007;22:95-102.

5. Brener B, Lisboa L, Mattos DPBG, Arashiro EKN, Millar PR, Sudré AP, et al. Freqüência de enteroparasitas em amostras fecais de cães e gatos dos municípios do Rio de Janeiro e Niterói. Rev Bras Ci Vet. 2005;12:102-5.

6. Bresciani KDS, Ishizaki MN, Kaneto CN, Montano TRP, Perri SHV, Vasconcelos $\mathrm{RO}$, et al. Frequiência e intensidade parasitária de helmintos gastrintestinais em cães na área urbana do município de Araçatuba, SP. Ars Vet. 2008;24:181-5.
7. Bridger KE, Whitney H. Gastrointestinal parasites in dogs from the Island of St. Pierre off the south coast of Newfoundland. Vet Parasitol. 2009;162:167-70.

8. Brooker S, Bethony J, Hotez PJ. Human hookworm infection in the $21^{\text {st }}$ century. Adv Parasitol. 2004;58:197-288.

9. Caumes E. It's time to distinguish the sign "creeping eruption" from the syndrome "cutaneous larva migrans". Dermatology. 2006;213:179-81.

10. Duarte A, Castro I, Pereira da Fonseca IM, Almeida V, Madeira de Carvalho LM, Meireles J, et al. Survey of infectious and parasitic diseases in stray cats at the Lisbon Metropolitan area, Portugal. J Feline Med Surg. 2010;12:441-6.

11. Foster AO, Cort WW. The stability of the cat and dog strains of Ancylostoma caninum J Parasitol. 1937;23:83-93.

12. Hoffmann, R.P. Diagnóstico de parasitismo veterinário. Porto Alegre: Sulina; 1987.

13. Ishizaki MN, Nascimento AA, Kaneto CN, Montano TRP, Perri SHV, Vasconcelos RO, et al. Freqüência e intensidade parasitária de helmintos gastrintestinais em felinos da zona urbana do município de Araçatuba, SP. Ars Vet. 2006;22:212-6.

14. Katagiri, S, Oliveira-Sequeira TCG. Zoonoses causadas por parasitas intestinais de cães e o problema do diagnóstico. Arq Inst Biol. 2007;74:175-84.

15. Klimpel S, Heukelbach J, Pothmann D, Rückert S. Gastrointestinal and ectoparasites from urban stray dogs in Fortaleza (Brazil): high infection risk for humans? Parasitol Res. 2010;107:713-9.

16. Landmann JK, Prociv P. Experimental human infection with the dog hookworm, Ancylostoma caninum. Med J Aust. 2003;178:69-71.

17. Millán J, Casanova JC. High prevalence of helminth parasites in feral cats in Majorca Island (Spain). Parasitol Res. 2009;106:183-8.

18. Mircean V, Titilincu A, Vasile C. Prevalence of endoparasites in household cat (Felis catus) populations from Transylvania (Romania) and association with risk factors. Vet Parasitol. 2010;171:163-6.

19. Moro FCB, Pradebon JB, Santos HT, Querol E. Ocorrência de Ancylostoma spp. e Toxocara spp. em praças e parques públicos dos municípios de Itaqui e Uruguaiana fronteira oeste do Rio Grande do Sul. Biodivers Pampeana. 2008;6:25-9.

20. Ogassawara S, Benassi S, Larsson CE, Leme PTZ, Hagiwara MK. Prevalência de infecções helmínticas em gatos na cidade de São Paulo. Rev Fac Med Vet Zootec Univ São Paulo. 1986;23:145-9.

21. Oliveira CB, Silva AS, Monteiro SG. Ocorrência de parasitas em solos de praças infantis nas creches municipais de Santa Maria - RS, Brasil. Rev FZVA. 2007;14:174-

22. Pfukenyi DM, Chipunga SL, Dinginya L, Matenga E. A survey of pet ownership, awareness and public knowledge of pet zoonoses with particular reference to roundworms and hookworms in Harare, Zimbabwe. Trop Anim Health Prod. 2010;42:247-52.

23. Ramírez-Barrios RA, Barboza-Mena G, Muñoz J, Angulo-Cubillán F, Hernández E, González F, et al. Prevalence of intestinal parasites in dogs under veterinary care in Maracaibo, Venezuela. Vet Parasitol. 2004;121:11-20.

24. Robertson ID, Thompson RC. Enteric parasitic zoonoses of domesticated dogs and cats. Microbes Infect. 2002;4:867-73.

25. Scaini CJ, Toledo RN, Lovatel R, Dionello MA, Gatti FA, Susin L, et al. Contaminação ambiental por ovos e larvas de helmintos em fezes de cães na area central do Balneário Cassino, Rio Grande do Sul. Rev Soc Bras Med Trop. 2003;36:617-9.

26. Scott JA. An experimental study of the development of Ancylostoma caninum in normal and abnormal hosts. Am J Epidemiol. 1928;8:158-204. 
COELHO, W.M.D.; AMARANTE, A.F.T.; APOLINÁRIO, J.C.; COELHO, N.M.D. \& BRESCIANI, K.D.S. - Occurrence of Ancylostoma in dogs, cats and public places from Andradina city, São Paulo State, Brazil. Rev. Inst. Med. Trop. Sao Paulo, 53(4): 181-4, 2011.

27. Santarém VA, Giuffrida R, Zanin GA. Larva migrans cutânea: ocorrência de casos humanos e identificação de larvas de Ancylostoma spp. em parque público do município de Taciba, São Paulo. Rev Soc Bras Med Trop. 2004;37:179-81.

28. Silva Francisco MM, Silva RC, Figueiredo DLV, Souza JN, Ramalho PCD, Caetano AL. Prevalência de ovos e larvas de Ancylostoma spp. e de Toxocara spp. em praças públicas da cidade de Anápolis-GO. Ensaios Ciênc. 2008;12:131-7.

29. Soulsby EJL. Helminths, arthropods, and protozoa of domesticated animals. $7^{\text {th }}$ ed. London: Baillière Tindall; 1982. p. 343-4.

30. Souza-Dantas LM, Bastos OPM, Brener B, Salomão M, Guerrero J, Labarthe NV. Técnica de centrífugo-flutuação com sulfato de zinco no diagnóstico de helmintos gastrintestinais de gatos domésticos. Ciênc Rural. 2007;37:904-6.
31. Yacob HT, Ayele T, Fikru R, Basu AK. Gastrointestinal nematodes in dogs from Debre Zeit, Ethiopia. Vet Parasitol. 2007;148:144-8.

32. Zago Filho H., Barreto MP. Estudo sobre a prevalência e intensidade de infestação por helmintos intestinais em cães e gatos de Ribeirão Preto, SP. Rev Bras Malar. 1957;9:295-304

Received: 26 November 2010

Accepted: 16 June 2011 